\title{
Changes in soil carbon and nutrients following 6 years of litter removal and addition in a tropical semi-evergreen rain forest
}

\author{
Edmund Vincent John Tanner ${ }^{1,2}$, Merlin W. A. Sheldrake ${ }^{1}$, and Benjamin L. Turner ${ }^{2}$ \\ ${ }^{1}$ Department of Plant Sciences, University of Cambridge, Downing St, Cambridge CB2 3EA, UK \\ ${ }^{2}$ Smithsonian Tropical Research Institute, Apartado 0843-03092, Balboa, Ancon, Republic of Panama \\ Correspondence to: Edmund Vincent John Tanner (evt1@cam.ac.uk)
}

Received: 25 May 2016 - Published in Biogeosciences Discuss.: 29 July 2016

Revised: 27 October 2016 - Accepted: 1 November 2016 - Published: 17 November 2016

\begin{abstract}
Increasing atmospheric $\mathrm{CO}_{2}$ and temperature may increase forest productivity, including litterfall, but the consequences for soil organic matter remain poorly understood. To address this, we measured soil carbon and nutrient concentrations at nine depths to $2 \mathrm{~m}$ after 6 years of continuous litter removal and litter addition in a semi-evergreen rain forest in Panama. Soils in litter addition plots, compared to litter removal plots, had higher $\mathrm{pH}$ and contained greater concentrations of KCl-extractable nitrate (both to $30 \mathrm{~cm}$ ); MehlichIII extractable phosphorus and total carbon (both to $20 \mathrm{~cm}$ ); total nitrogen (to $15 \mathrm{~cm}$ ); Mehlich-III calcium (to $10 \mathrm{~cm}$ ); and Mehlich-III magnesium and lower bulk density (both to $5 \mathrm{~cm}$ ). In contrast, litter manipulation did not affect ammonium, manganese, potassium or zinc, and soils deeper than $30 \mathrm{~cm}$ did not differ for any nutrient. Comparison with previous analyses in the experiment indicates that the effect of litter manipulation on nutrient concentrations and the depth to which the effects are significant are increasing with time. To allow for changes in bulk density in calculation of changes in carbon stocks, we standardized total carbon and nitrogen on the basis of a constant mineral mass. For $200 \mathrm{~kg} \mathrm{~m}^{-2}$ of mineral soil (approximately the upper $20 \mathrm{~cm}$ of the profile) about $0.5 \mathrm{~kg} \mathrm{C} \mathrm{m}^{-2}$ was "missing" from the litter removal plots, with a similar amount accumulated in the litter addition plots. There was an additional $0.4 \mathrm{~kg} \mathrm{C} \mathrm{m}^{-2}$ extra in the litter standing crop of the litter addition plots compared to the control. This increase in carbon in surface soil and the litter standing crop can be interpreted as a potential partial mitigation of the effects of increasing $\mathrm{CO}_{2}$ concentrations in the atmosphere.
\end{abstract}

\section{Introduction}

Tropical forests and their soils are an important part of the global carbon (C) cycle because they contain $692 \mathrm{PgC}$, equivalent to $66 \%$ of the $\mathrm{C}$ in atmospheric $\mathrm{CO}_{2}$ (Jobbagy and Jackson, 2000). Carbon in tropical forest soils is dynamic: Schwendenmann and Pendall (2008) reported a turnover time of 15 years for the "slow" pool of soil C, comprising $38 \%$ of the total soil $\mathrm{C}$, in the top $10 \mathrm{~cm}$ of soil in semi-evergreen rain forest on Barro Colorado Island, Panama (61\% of total soil C was "passive" with a turnover time of the order of a 1000 years). Turner et al. (2015) reported an approximate $25 \%$ increase in soil C from one dry season to the next wet season in the top $10 \mathrm{~cm}$ of soil on the Gigante Peninsula in Barro Colorado Nature Monument, Panama, at a site close to the current litter manipulation experiment. Thus, there is the potential for the amount of $\mathrm{C}$ in tropical soils to change over only a few years, with potentially important consequences for atmospheric $\mathrm{CO}_{2}$ concentrations.

Atmospheric $\mathrm{CO}_{2}$ concentrations have been steadily increasing for decades and one of the effects of this could be widespread increases in forest growth (Nemani et al., 2003) and, as a result, increased litterfall. There are few experimental studies of the effects of elevated $\mathrm{CO}_{2}$ on forest growth. Körner (2006) reported that elevated $\mathrm{CO}_{2}$ caused increased litterfall in one of three studies in steady-state tree stands in temperate forests, but there have been no such studies in the tropics. Thus, the potential exists for increased $\mathrm{CO}_{2}$ to increase forest growth and litterfall - though we do not know how widespread and how large any increase in litterfall might be, especially in the tropics. 
Soil $\mathrm{C}$ has been shown to respond to experimental changes in litter inputs. In three studies in temperate forests in the USA, litter removal always resulted in lower soil organic carbon, but litter addition had much more variable effects, increasing in one (Lajtha et al., 2014a), not changing in the second (Bowden et al., 2014) and decreasing in the third (Lajtha et al., 2014b). The single study from the tropics, in lowland rain forest in southwestern Costa Rica, reported decreased soil $\mathrm{C}$ in litter removal plots and increased soil $\mathrm{C}$ in litter addition plots (Leff et al., 2012). It is therefore likely that soil $\mathrm{C}$ will increase in many, but not all, forests as a result of increased litter input.

The relative importance of above-ground or below-ground inputs as sources of soil organic matter has been reassessed in the last decade (Schmidt et al., 2011). Recently it was shown that $50-70 \%$ of the soil organic matter in boreal coniferous forest is from roots and root-associated microorganisms (Clemmensen et al., 2013). The origin of the soil organic matter is thus a question of the relative contributions of above-ground and below-ground inputs. Litter manipulation experiments can provide insights into this issue by controlling one source of $\mathrm{C}$ input - above-ground litterfall.

Soil nutrients as well as $\mathrm{C}$ can change as a result of increasing or decreasing litter inputs and are important because they will potentially affect soil fertility. In Panama, mineralization of organic phosphorus (P) (inferred from the decrease in the concentration of organic P) in the top $2 \mathrm{~cm}$ of soil during 3 years of litter removal was calculated to be sufficient to supply $20 \%$ of the P needed to sustain forest growth - there were corresponding increases in organic $\mathrm{P}$ in litter addition plots, and total nitrogen $(\mathrm{N})$ showed a similar pattern (Vincent et al., 2010). "Available" nutrients, including KCl-extractable ammonium $\left(\mathrm{NH}_{4}\right)$ and nitrate $\left(\mathrm{NO}_{3}\right)$ and Mehlich-III extractable $\mathrm{P}$, potassium $(\mathrm{K})$, calcium $(\mathrm{Ca})$, magnesium $(\mathrm{Mg})$ and micronutrients, all changed over 4 years in the upper $2 \mathrm{~cm}$ of soil as a result of litter manipulation (Sayer and Tanner, 2010). After 6 years of litter manipulation, surface soils $(0-10 \mathrm{~cm})$ had lower $\mathrm{NO}_{3}$ and $\mathrm{K}$ in litter removal plots and higher $\mathrm{NO}_{3}$ and $\mathrm{Zn}$ in litter addition plots; other nutrients were not significantly affected (Sayer et al., 2012). In Costa Rica after 2.5 years of litter manipulation, surface soils (0$10 \mathrm{~cm}$ ) had lower net nitrification in both litter removal and addition treatments, while $\mathrm{NH}_{4}$ concentrations were significantly lower in litter removal plots $\left(\mathrm{NH}_{4}\right.$ was $83-91 \%$ of the extractable N; Wieder et al., 2013). Thus, several soil nutrients in surface soils change following litter manipulation, but there is no consistent pattern for $\mathrm{N}$, very little data for $\mathrm{P}$ or cations (the latter were not reported for the Costa Rican experiment), and no data for soils deeper than $10 \mathrm{~cm}$.

Here we report results from the Gigante Litter Manipulation Plots (GLiMP) experiment over a much greater soil depth $(0-200 \mathrm{~cm})$ for total $\mathrm{C}, \mathrm{N}$ and $\mathrm{P}$ and for extractable ("plant-available") N, P, K, Ca, Mg, manganese (Mn) and zinc $(\mathrm{Zn})$, measured after 6 years of continuous litter transfer. In addition, we present a new way of expressing soil $\mathrm{C}$ (relative to the unchanging mineral mass), which allows us to calculate overall changes in soil $\mathrm{C}$ and other elements independently of changes in bulk density. Our objective was to describe changes in $\mathrm{C}$ and nutrient concentrations in the full soil profile and to calculate $\mathrm{C}$ budgets to discover the fate of the increased $\mathrm{C}$ input in litter addition plots. In particular, we aimed to calculate the proportion of the added $\mathrm{C}$ that remains in the soil and the litter standing crop and can thus be considered as partial mitigation of atmospheric $\mathrm{CO}_{2}$ accumulation through increased forest productivity due to increased atmospheric $\mathrm{CO}_{2}$ and temperature - mitigation because $\mathrm{C}$ that is not in the soil will be in the atmosphere as extra $\mathrm{CO}_{2}$. No other study has tried to quantify the fate of $\mathrm{C}$ in organic matter added to tropical forest soils, though a study of agricultural soil in the temperate UK calculated that about $2.4 \%$ of organic matter in annual additions of farmyard manure was still in the soil after 120 years (Powlson et al., 2011).

\section{Materials and methods}

The litter manipulation experiment is located in old-growth semi-evergreen lowland tropical forest on the Gigante Peninsula $\left(9^{\circ} 06^{\prime} \mathrm{N}, 79^{\circ} 54^{\prime} \mathrm{W}\right)$, part of the Barro Colorado Nature Monument in central Panama. The experiment is located on the upper part of the landscape, where soils are Oxisols (Typic Kandiudox). Surface soils have a pH of 4.5-5.0 and low available $\mathrm{P}$ concentrations but high base saturation and cation exchange capacity. Annual rainfall on nearby Barro Colorado Island (ca. $5 \mathrm{~km}$ from the study site) is $2600 \mathrm{~mm}$ and average temperature is $27^{\circ} \mathrm{C}$. There is a strong dry season from January to April, with approximately $90 \%$ of the annual precipitation during the rainy season.

The experiment consists of fifteen $45 \mathrm{~m} \times 45 \mathrm{~m}$ plots within a 40 ha area of old-growth forest. In 2001 all 15 plots were trenched to a depth of $0.5 \mathrm{~m}$ to minimize lateral nutrient and water movement via the root-mycorrhizal network; the trenches were double-lined with plastic and backfilled. Beginning in January 2003, litter (including branches $<20 \mathrm{~mm}$ in diameter) was raked up once a month in five plots, resulting in low, but not entirely absent, litter standing crop (litter removal plots). The removed litter was immediately spread on five further plots (litter addition plots), with five plots left as controls (CT plots). Treatments were assigned on a stratified random basis using total litterfall per plot in 2002 (i.e. the three plots with highest litterfall were randomly assigned to treatments, then the next three and so on) (Sayer et al., 2007). The plots were geographically blocked, litter from a particular litter removal plot was always added to a particular litter addition plot and there was a nearby control plot.

Soils samples were collected in January 2009, the early dry season, using a $7.6 \mathrm{~cm}$ diameter constant volume corer for the top $20 \mathrm{~cm}$ of soil and a $7 \mathrm{~cm}$ diameter auger for 20$200 \mathrm{~cm}$. Fresh soils were extracted for $\mathrm{NO}_{3}$ and $\mathrm{NH}_{4}$ within $2 \mathrm{~h}$ of sampling in a $2 \mathrm{M} \mathrm{KCl}$ solution, with detection by 
automated colorimetry on a Lachat Quikchem 8500 (Hach Ltd, Loveland, CO). Phosphorus and cations were extracted within $24 \mathrm{~h}$ in Mehlich III solution and analysed by inductively coupled plasma optical emission spectrometry (ICPOES). Soil $\mathrm{pH}$ was measured on a $1: 2$ fresh soil solution in distilled water.

Dried $\left(22^{\circ} \mathrm{C} \times 10 \mathrm{~d}\right)$ and ground soil was analysed for total $\mathrm{C}$ and $\mathrm{N}$ by combustion and gas chromatography on a Flash 1112 analyzer (Thermo, Bremen, Germany). Total P was determined by ignition at $550^{\circ} \mathrm{C}$ for $1 \mathrm{~h}$ and extraction for $16 \mathrm{~h}$ in $1 \mathrm{M} \mathrm{H}_{2} \mathrm{SO}_{4}$, with detection by automated molybdate colorimetry at $880 \mathrm{~nm}$ using a Lachat Quikchem 8500 (Hach Ltd, Loveland, CO).

Nutrient data were analysed using mixed-effects models, with "litter treatment", "depth" and their interaction as fixed effects and "plot" as a random effect. Where nutrient concentrations varied non-linearly with depth, we used splines with two or three knots. Some nutrients showed severe heteroscedasticity, and we accounted for this in the model by using "variance covariates", which model the variance as a function of one or more of the effects in the model (Pinheiro and Bates, 2000; Zuur et al., 2009). For all nutrients, depth was modelled as a numeric predictor and log transformed prior to analysis. We performed model selection based on likelihood ratio tests and the Aikake information criterion with correction for small sample sizes (AICc; Burnham and Anderson, 2002). We derived $P$ values for fixed effects by comparing null models to full models using likelihood ratio tests. Final models were refitted using restricted maximum likelihood estimation (REML) (Zuur, 2009). Where the treatment $\times$ depth term was significant, we refitted the model omitting either the litter addition treatment or the litter removal treatment to assess the contribution of each of the treatments (litter addition and litter removal) to the overall interaction term. Analyses were done in $\mathrm{R}$ version 3.1.2.

Amounts of soil total $\mathrm{C}$ and $\mathrm{N}$ were also calculated relative to soil mineral mass to allow comparisons between the treatments where bulk density and soil depth was changing due to removal and addition of litter; soil in litter removal plots was shrinking and had increasing bulk density; soil in litter addition plots was increasing in depth and had lower bulk density. Expressing potentially changing elements relative to unchanging mineral mass allows for change to be expressed against an unchanging reference; it is analogous to expressing soil water relative to soil dry mass rather than soil fresh mass. Soil organic $\mathrm{C}$ with depth was calculated for each plot by fitting a line to cumulative soil organic $\mathrm{C}(Y)$ against cumulative soil mineral mass $(X)$. Bulk density data were measured for each plot only in the top $0-5 \mathrm{~cm}$ for soil. Below that we used bulk density data for one pit only. Bulk density below $10 \mathrm{~cm}$ depth does not vary much across the site; data for four soil pits (not in any of the plots) have a coefficient of variation of about $10 \%$ for soils from $10-20 \mathrm{~cm}$ depth and $3 \%$ for soils from $20-50 \mathrm{~cm}$ depth), whereas coefficients of variation of bulk densities in surface $0-5 \mathrm{~cm}$ soils were higher: control $12 \%$, litter addition $15 \%$ and litter removal $4.9 \%$. Bulk density data were used to estimate approximate soil depth for control plots in Figs. 3 and 4. Statistical comparisons of modelled cumulative total $\mathrm{C}$ against cumulative mineral matter were compared by bootstrapping, using $\mathrm{R}$ version 3.1.2.

\section{Results}

Soils in litter addition plots, compared to litter removal plots, had significantly lower bulk density (both to $5 \mathrm{~cm}$ ) and higher $\mathrm{NO}_{3}$ and $\mathrm{pH}$ (to $30 \mathrm{~cm}$ ), $\mathrm{P}_{\mathrm{Meh}}$ and total $\mathrm{C}$ (both to $20 \mathrm{~cm}$ ), total $\mathrm{N}$ (to $15 \mathrm{~cm}$ ), $\mathrm{Ca}$ (to $10 \mathrm{~cm}$ ), and $\mathrm{Mg}$ (to $5 \mathrm{~cm}$ ) (Figs. 1 and 2 and Supplement Tables S1 and S2). There were fewer differences when compared to control soils: litter addition soils had higher concentrations of $\mathrm{P}_{\mathrm{Meh}}$ (to $20 \mathrm{~cm}$ ), $\mathrm{NO}_{3}$ (to $15 \mathrm{~cm}$ ), $\mathrm{Ca}$ (to $10 \mathrm{~cm}$ ) and $\mathrm{pH}$ (to $10 \mathrm{~cm}$ ). Nutrient concentrations in litter removal soils were not significantly lower than those in controls. Nutrient concentrations in soils $>30 \mathrm{~cm}$ deep did not differ significantly for any nutrient. Thus, in some way total $\mathrm{C}$, total $\mathrm{N}, \mathrm{NO}_{3}, \mathrm{P}_{\mathrm{Meh}}, \mathrm{Ca}$ and $\mathrm{Mg}$ were significantly affected by litter removal or addition, but $\mathrm{K}, \mathrm{Mn}$, $\mathrm{NH}_{4}, \mathrm{Zn}$ and were not; effect sizes (log response ratio for $0-$ $5 \mathrm{~cm}$ soils) decreased from 0.81 for $\mathrm{NO}_{3}$ to 0.39 for $\mathrm{Ca}, 0.27$ for $\mathrm{Zn}, 0.20$ for $\mathrm{P}_{\mathrm{Meh}}, 0.20$ for $\mathrm{Mg}, 0.15$ for $\mathrm{C}_{\text {tot }}$ and 0.11 for $\mathrm{N}_{\text {tot. }}$.

All nutrients decreased in concentration with increasing soil depth. In control soils, concentrations at 50-100 cm compared to 0-5 cm were as follows: $\mathrm{NH}_{4} 50 \%, \mathrm{Mg} 37 \%, \mathrm{P}_{\text {tot }}$ $36 \%, \mathrm{~K} 32 \%, \mathrm{P}_{\text {Meh }} 25 \%, \mathrm{NO}_{3} 24 \%, \mathrm{~N}_{\text {tot }} 12 \%, \mathrm{Ca} 11 \%$ and $\mathrm{C}_{\text {tot }} 11 \% ; \mathrm{NO}_{3}$ was only $24 \%$ of the total inorganic $\mathrm{N}$ in controls (mean over all depths) (Figs. 1 and 2 and Table S1). Concentrations of most elements continued to decrease below $100 \mathrm{~cm}$ depth in the soil; those from $150-200 \mathrm{~cm}$ were about half those from $50-100 \mathrm{~cm}$ (ranging from $14 \%$ for $\mathrm{Ca}$ to $81 \%$ for $\mathrm{NH}_{4}$; Table $\mathrm{S} 1$ ).

Soil bulk density in the top $5 \mathrm{~cm}$ was significantly lower in litter addition than litter removal, though neither was significantly different from the controls. Soil C stocks standardized to a consistent mineral mass (i.e. that in the control plots) was significantly greater in litter addition compared to litter removal to about $10 \mathrm{~cm}$ depth in the soil (Figs. 3 and 4). Total $\mathrm{N}$ per mineral mass of soil was also significantly greater in litter addition than litter removal in approximately the top $10 \mathrm{~cm}$ of soil. In contrast, $\mathrm{C}: \mathrm{N}$ ratios changed little with depth. In control soils, $\mathrm{C}: \mathrm{N}$ was about 10.5 near the surface and 10.0 at $150-200 \mathrm{~cm}$; in litter removal plots, $C: N$ was 10.5 at the surface and 10.3 at depth, while litter addition soils were more variable, with $\mathrm{C}: \mathrm{N}$ being 11.7 at the surface and about 10.0 at $150-200 \mathrm{~cm}$ depth. 

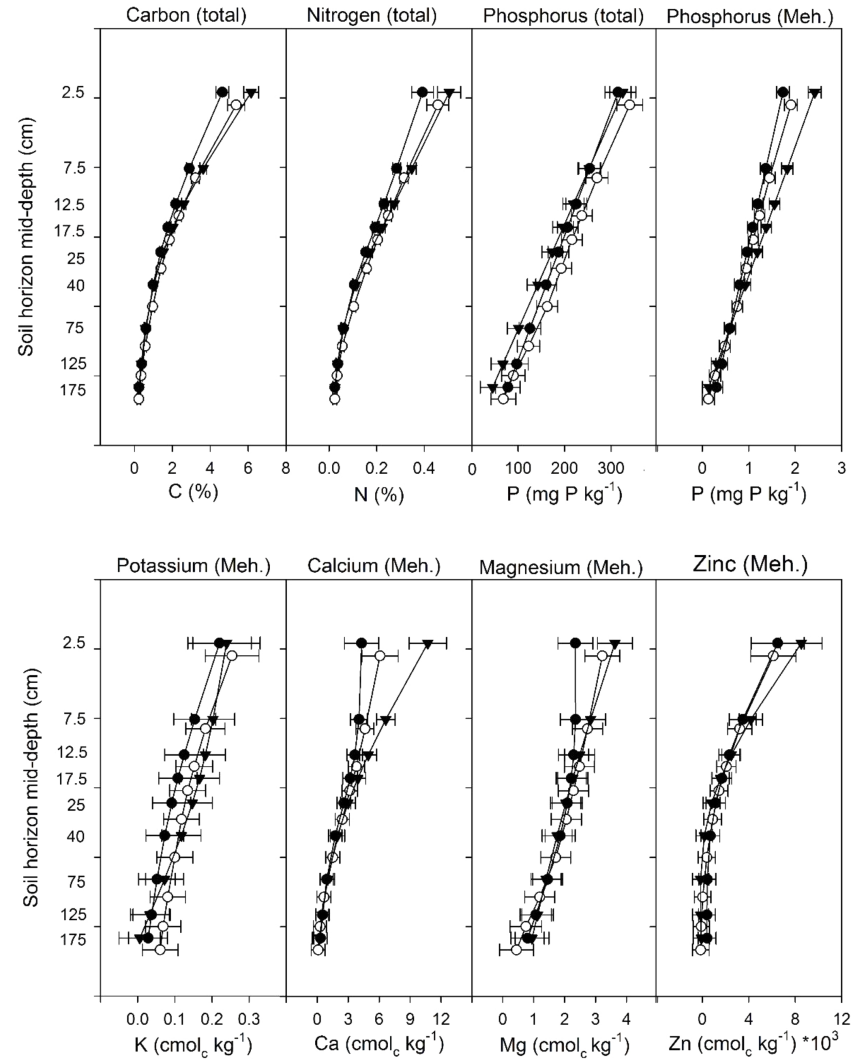

Figure 1. Concentrations of soil C, N, P (various fractions) and cations (Mehlich extractions), plotted against the midpoint of the soil layers sampled (Zn values should be divided by 1000 to obtain actual means); control points are displaced below treatments. Data are fitted values of the mixed-effects models with $95 \%$ confidence intervals (see the "Material and methods" section) in litter removal $\bullet$, control $\circ$ and litter addition $\mathbf{\nabla}$ plots.

\section{Discussion}

\subsection{Soil carbon dynamics}

The amount of C "missing" from litter removal and "extra" in the litter addition over about the top $20 \mathrm{~cm}$ of soil (from calculations based on $\mathrm{C}$ per mineral matter), 6 years after (January 2009) litter removal and addition started, was about $0.5 \mathrm{~kg} \mathrm{C} \mathrm{m}^{-2}$ (Fig. 3). These changes are ca. $1 \%$ per year; in contrast if we calculate the change based on a fixed depth of $20 \mathrm{~cm}$, ignoring changes in bulk density, we get a change of about $2 \%$ per year. Thus, ignoring the changes in bulk density results in a misleading doubling of the estimated rate of change. The similarity of the losses from litter removal and gains in litter addition probably has different causes: we speculate that losses from the soil in the litter removal plots are due to respiration being greater than additions; we did not physically remove organic matter from the mineral soil. We further speculate that increases in $\mathrm{C}$ in the mineral soil in the litter addition plots are a result of infiltration of dis-

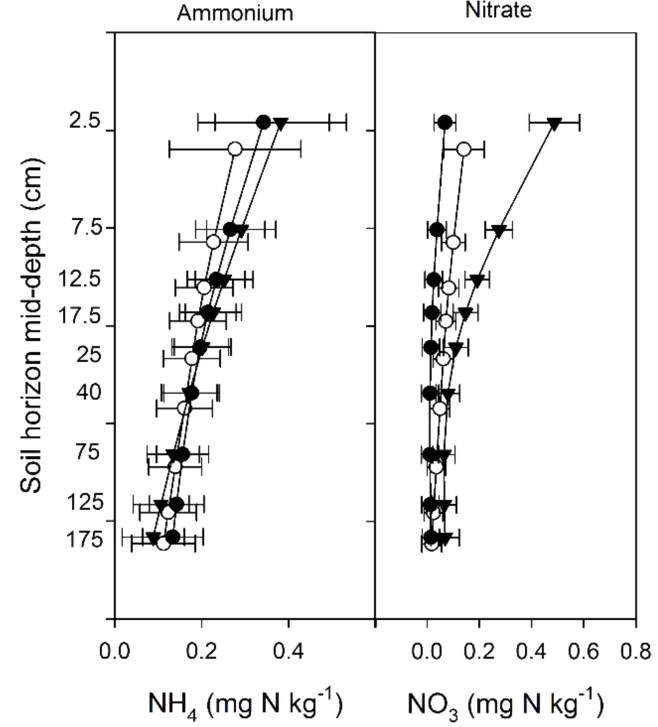

Figure 2. Mean concentrations of ammonium and nitrate plotted against the midpoint of the soil layers sampled; control points are displaced below treatments. Data are fitted values of the mixedeffects models with $95 \%$ confidence intervals (see the "Material and methods" section) in litter removal •, control $\circ$ and litter addition $\nabla$ plots.

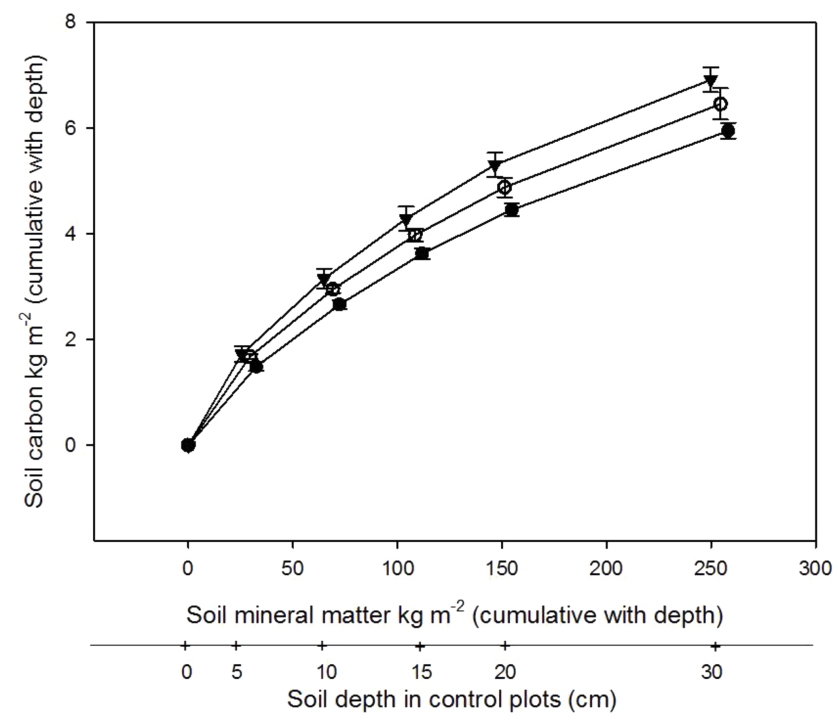

Figure 3. Soil carbon content and mineral content in litter addition, control and litter addition, expressed as $\mathrm{kg} \mathrm{C} \mathrm{m}^{-2}$ cumulatively from 0 to $30 \mathrm{~cm}$ soil depth. Values are means for five plots per treatment $\pm \mathrm{SE}$; litter removal $\bullet$, control $\circ$ and litter addition $\mathbf{\nabla}$.

solved and particulate organic matter draining from the litter standing crop and/or changes in root exudates; increases in root growth are not the explanation - root growth was lower in litter addition plots (Sayer et al., 2006).

In addition to the extra soil $\mathrm{C}$ in the litter addition plots, the litter standing crop was also larger in litter addition plots. In 


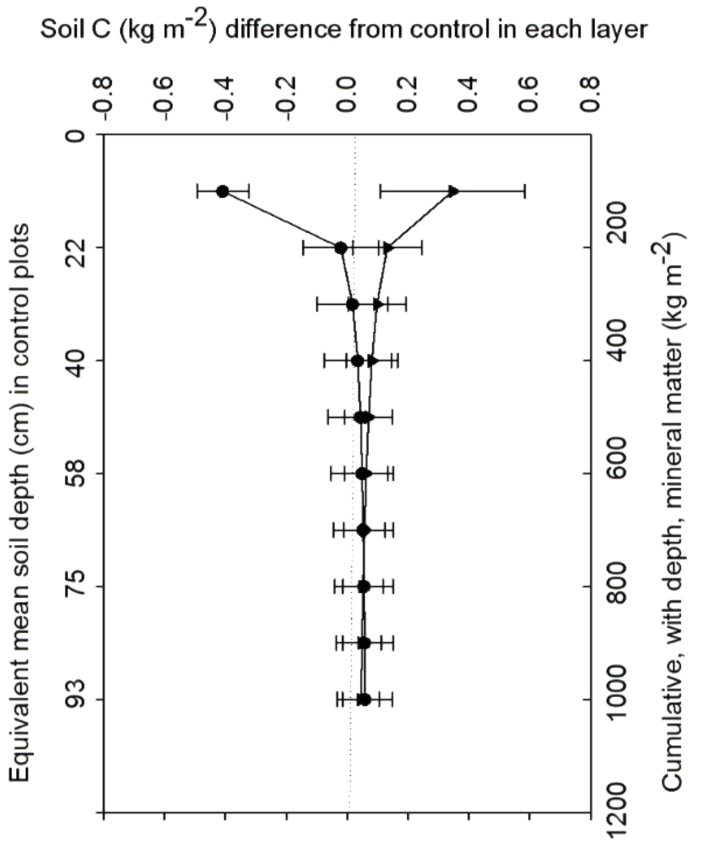

Figure 4. Differences in soil carbon content relative to control soils (mean and SE; $n=5$ ), after 6 years of litter manipulation, plotted for successive soil layers: $0-100 \mathrm{~kg}$ (mineral matter) $\mathrm{m}^{-2}$, plotted at $100 \mathrm{~kg} \mathrm{~m}^{-2}$ on right $y$ axis; $100-200 \mathrm{~kg} \mathrm{~m}^{-2}$, plotted at $200 \mathrm{~kg} \mathrm{~m}^{-2}$; and so on to $900-1000 \mathrm{~kg} \mathrm{~m}^{-2}$, plotted at $1000 \mathrm{~kg} \mathrm{~m}^{-2}$ in litter removal $\bullet$ and litter addition $\boldsymbol{\nabla}$ plots. We calculated the soil $\mathrm{C}$ in the litter removal and litter addition plots at the mineral mass equal to that at various depths in the control plots $(0$ $5,5-10 \mathrm{~cm}$, etc.). We then calculated the difference in $\mathrm{C}$ between each litter removal (or litter addition) and its control plot for the same mineral mass. Approximate depth for cumulative soil mineral mass in control plots is shown on left $y$ axis.

September 2005 (2.8 years after litter manipulation started), there was an additional $0.4 \mathrm{~kg} \mathrm{C} \mathrm{m}^{-2}$ in the Oi and Oe layers compared to control plots (Sayer and Tanner, 2010), and data from 2013 show that litter standing crop was at about this level (C. Rodtassana, University of Cambridge, unpublished data). Together this extra $0.9 \mathrm{~kg} \mathrm{C} \mathrm{m}^{-2}$ in the litter addition soil and litter standing crop is about $30 \%$ of the $3 \mathrm{~kg} \mathrm{C} \mathrm{m}^{-2}$ in litter added to the litter addition plots over 6 years (litterfall is ca. $1 \mathrm{~kg} \mathrm{~m}^{-2} \mathrm{yr}^{-1}$, ca. $45 \%$ is $\mathrm{C}$, times 6 years). This increase in $\mathrm{C}$ in surface soil and the litter standing crop could be interpreted as potential partial mitigation of the effects of increasing $\mathrm{CO}_{2}$ concentrations in the atmosphere, though any increases in litterfall due to increased $\mathrm{CO}_{2}$ will be less than our experimental doubling. For example, a freeair $\mathrm{CO}_{2}$ experiment in a 13-year-old loblolly pine plantation in North Carolina USA reported a $12 \%$ increase in litterfall over 9 years (Lichter et al., 2005, 2008).
The increases in soil $\mathrm{C}$ in our litter addition plots (ca. $1 \%$ per year, of total $\mathrm{C}$ to ca. $20 \mathrm{~cm}$ depth) are much smaller than those reported in the other study of litter manipulation in tropical forest (lowland rain forest in southwestern Costa Rica), where 2 years of litter removal reduced soil $\mathrm{C}$ concentration in the top $10 \mathrm{~cm}$ of soil by $26 \%$ and doubling litter increased soil C by $31 \%$ (Leff et al., 2012). In three temperate forest studies, rates of change in soil $\mathrm{C}$ were small, but they were measured over much longer periods. In the north central USA, soil C content decreased by $44 \%$ in litter removal plots and increased by $31 \%$ in double litter plots over a 50-year period (Table 2 in Lajtha et al., 2014a). In Pennsylvania, USA, 20 years of removing litter reduced soil C by $24 \%$, although the corresponding litter doubling had no effect (Bowden et al., 2014). In a deciduous forest in Massachusetts, USA, 20 years of litter removal also reduced mineral soil C (by $19 \%$ ), but litter addition also resulted in lower mineral soil C (by 6\%, Lajtha et al., 2014b). Differences between forests in the effect of litter addition on soil organic matter could be partly due to differences in priming of preexisting soil organic $\mathrm{C}$ resulting in no, or small, increases in soil $\mathrm{C}$ in double litter plots. Priming might be greater in $\mathrm{N}$-limited temperate forests remote from atmospheric $\mathrm{N}$ pollution because one cause of priming is mining of soil organic matter for $\mathrm{N}$ by microbes stimulated by additions of litter with low $\mathrm{N}$ concentrations (relative to soil organic matter) (e.g. Nottingham et al., 2015). It is therefore likely that many, but not all, forests will show increased $\mathrm{C}$ in soils as a result of increased litter input.

Soil C might on average originate predominantly from roots rather than shoots (Rasse et al., 2005), and that may be the case in our soils in Panama because although changes in litter inputs have caused changes in soil C, they are small - approximately $1 \%$ of total soil $\mathrm{C}$ per year - compared to the "normal" turnover of $\mathrm{C}$ of $25 \%(0-10 \mathrm{~cm}$ soil) within 6 months (as calculated from changes in $\mathrm{C}$ concentration from wet season to dry season; Turner et al., 2015) and an annual turnover of about $7 \%$ based on incorporation of ${ }^{13} \mathrm{C}$ into soils over decades (Schwendenmann and Pendall, 2008). Turnover rates of soil $\mathrm{C}$ are also high in other tropical forests; for example, in eastern Brazil $40-50 \%$ of the $\mathrm{C}$ in the top $40 \mathrm{~cm}$ of soil had been fixed in about 32 years (Trumbore, 2000). In Panama the much greater rates of turnover of soil $\mathrm{C}$ as compared to changes caused by litter removal and addition suggest that the main source of soil organic matter (over months to a few years) is roots, root exudates and mycorrhizal fungi. Nevertheless, changes in above-ground litter input are still important because they have resulted in overall decreases and increases in soil C.

\subsection{Litter manipulation - depth of effects}

Effects of litter removal and addition differed among nutrients and were strongest near the soil surface, with no significant differences below $30 \mathrm{~cm}$. The strength of the effects 
and the depth to which they were significant are increasing with time. Four years after the start of litter manipulation, six nutrients showed significant effects in the upper $2 \mathrm{~cm}$ of soil $\left(\mathrm{NO}_{3}, \mathrm{NH}_{4}, \mathrm{P}_{\text {Meh }}, \mathrm{K}, \mathrm{Ca}, \mathrm{Mg}\right)$, whereas only $\mathrm{NO}_{3}$ and $\mathrm{Ca}$ showed significant effects from $0-10 \mathrm{~cm}$ (Sayer et al., 2010). After 6 years, in the early dry season 2009 (current paper), effects were seen to greater depths: $\mathrm{NO}_{3}$ was higher to $30 \mathrm{~cm}$ and $\mathrm{P}_{\mathrm{Meh}}$ to $20 \mathrm{~cm}$ in litter addition plots. Over time significant differences have become apparent for more nutrients and to greater depth in the soil; these differences were caused by differences in litter input.

The concentrations of $\mathrm{NH}_{4}$ and $\mathrm{NO}_{3}$ are usually only measured in surface soils in tropical rain forests, perhaps because $\mathrm{N}$ is generally thought not to limit growth in such forests. However, fertilization with $\mathrm{N}$ and $\mathrm{K}$ together increased growth of saplings and seedlings in the Gigante Fertilization Project, which is adjacent to our litter manipulation experiment in Panama (Wright et al., 2011). Relevant concentrations of $\mathrm{NH}_{4}$ and $\mathrm{NO}_{3}$ are also difficult to measure since they change rapidly over only a few hours (Turner and Romero, 2009); extractions for the current paper were done within $2 \mathrm{~h}$ of collecting soils. In our litter manipulation experiment, $\mathrm{NH}_{4}$ accounted for $76 \%$ of the sum of $\mathrm{NH}_{4}$ and $\mathrm{NO}_{3}$ (mean over all depths in controls plots) and decreased less with depth than $\mathrm{NO}_{3}$ (at $50-100 \mathrm{~cm} \mathrm{NH}$ was about $50 \%$ of surface values, whereas $\mathrm{NO}_{3}$ was about $25 \%$ ). In the nutrient addition experiment, Koehler et al. (2012) reported that $\mathrm{NH}_{4}$ also decreased less with depth (at $200 \mathrm{~cm}$ it was $41 \%$ of surface soils) than $\mathrm{NO}_{3}$ (to $17 \%$ of surface soils) and that $\mathrm{NH}_{4}$ was the dominant form of total inorganic $\mathrm{N}$ (about 80\%) the same patterns as in our litter manipulation experiment. Nitrogen dynamics in soils have also been measured in a litter manipulation experiment in Costa Rica (Wieder et al., 2013), where nitrification rates were lower in both litter removal and litter addition plots and extractable $\mathrm{NH}_{4}$ was significantly lower in litter removal plots. This contrasts with our results of greater $\mathrm{NO}_{3}$ in litter addition compared to litter removal and no effect on $\mathrm{NH}_{4}$; the differences between the experiments might be due in part to different soils and a wetter climate in Costa Rica (ca. $5 \mathrm{~m}$ rain per year, cf. $2.6 \mathrm{~m}$ in Panama). Thus, soil $\mathrm{N}$ dynamics differ somewhat between the only two tropical litter manipulation experiments, but in both $\mathrm{NH}_{4}$ was the dominant form of inorganic $\mathrm{N}$ and in both total inorganic $\mathrm{N}$ decreased in litter removal plots and increased in litter addition plots (though differences were not always statistically significant).

The available forms of $\mathrm{P}$ are also not often reported for the deeper horizons of tropical forest soils, despite the fact that $\mathrm{P}$ is usually regarded as the most likely limiting nutrient in such forests (Tanner et al., 1998 and Cleveland et al., 2011) and has been shown to limit fine-litter production in the adjacent nutrient addition experiment (Wright et al., 2011). Mehlich $\mathrm{P}$ and total $\mathrm{P}$ both decreased with depth in control soils in our litter manipulation experiment (at 50-100 cm concentrations were 25 and $29 \%$ of those at $0-5 \mathrm{~cm}$ ); in litter removal soils the decrease was less steep (37 and 36\%). Litter addition increased Mehlich P in the surface soils (though total $\mathrm{P}$ was not significantly greater), indicating increased $\mathrm{P}$ availability, which is consistent with the finding that litter addition decreased the strength of phosphate sorption in these soils (Schreeg at al., 2013). Thus, for P, potentially the most commonly limiting nutrient in tropical rain forest soils, 6 years of continuous removal and addition of litter in our experiment has reduced and increased available $P$ down to $20 \mathrm{~cm}$ in the soil.

The relative amounts of exchangeable cations and their change with depth in the control plots of the Panamanian litter manipulation soils are similar to patterns in other tropical forest soils. In our experiment, Ca concentrations (in centimoles of charge) are about twice those of $\mathrm{Mg}$ in surface soils (though below $30 \mathrm{~cm}$ Mg-to-Ca ratios exceed 1); K concentrations are usually less than $5 \%$ of the total exchangeable bases. With increasing depth, $\mathrm{Ca}, \mathrm{Mg}$ and $\mathrm{K}$ concentrations all decrease, with $\mathrm{Ca}$ decreasing more than $\mathrm{Mg}$ or $\mathrm{K}$. Other tropical forest soils are similar: in 19 profiles throughout Amazonia the sum of base cations $(\mathrm{Ca}, \mathrm{Mg}, \mathrm{K})$ was usually dominated by exchangeable $\mathrm{Ca}$ ( 11 cases) or $\mathrm{Ca}$ was equal to $\mathrm{Mg}$ (4 cases), and both $\mathrm{Ca}$ and $\mathrm{Mg}$ mostly decreased with depth, while $\mathrm{K}$ was in low or in trace concentrations in all profiles (Quesada et al., 2011). In Hawaii (Porder and Chadwick, 2009), much younger soils (11000 BP on lava), with much higher concentrations of $\mathrm{Ca}, \mathrm{Mg}$ and $\mathrm{K}$ than in Panama and Amazonia, showed similar patterns: $\mathrm{Ca}$ was the dominant cation, $\mathrm{K}$ was usually less than $5 \%$ of the sum of exchangeable $\mathrm{Ca}, \mathrm{Mg}$ and $\mathrm{K}$, and all cations decreased with depth at the wetter sites (but not at the drier sites). Thus, in most wet tropical forest soils, $\mathrm{Ca}$ is the most abundant cation and most cations decrease with depth. Litter addition in Panama increased $\mathrm{Ca}$ and $\mathrm{Mg}$ concentrations in the surface soils and thus steepened the depth gradient, whereas litter removal decreased $\mathrm{Ca}$ and $\mathrm{Mg}$ and therefore decreased the gradient; $\mathrm{K}$ was at much lower concentrations (as in Amazonia and Hawaii) and was not affected by litter addition and litter removal even in $0-5 \mathrm{~cm}$ soils.

\subsection{Design of litter manipulation experiments}

The design of litter manipulation experiments needs to be carefully considered when evaluating their results. The strength of the effect of litter manipulation on soil $\mathrm{C}$ in Panama was much less than that in Costa Rica, but the Panama and Costa Rica experiments are very different in spatial scale. Plots in Panama are large $(45 \times 45 \mathrm{~m})$; those in Costa Rica are small $(3 \times 3 \mathrm{~m})$. The small plots are "hot" and "cold" spots relative to large individual tree crown areas (and likely tree root areas); crowns of the largest trees in lowland rain forests are commonly $25 \mathrm{~m}$ in diameter, so a $3 \times 3 \mathrm{~m}$ plot is $2 \%$ of that area. These differences in experimental design and their effects on the pattern of the results should be considered when trying to understand ecosystem 
level processes; small hot and cold spots may not represent what would happen in plots on the scale of the large trees, as pointed out by Leff et al. (2012).

\section{Conclusions}

The increase in $\mathrm{C}$ in the mineral soil and the litter standing crop following litter addition was statistically significant in the top $20 \mathrm{~cm}$ of the soil, suggesting that any increased litterfall as a result of increased atmospheric $\mathrm{CO}_{2}$ and/or temperature could result in a substantial increase in soil $\mathrm{C}$ and therefore partially mitigate the increase in atmospheric $\mathrm{CO}_{2}$. However, the current experiment added much more litter than might be produced by an increase in $\mathrm{CO}_{2}$ of, say, $200 \mathrm{ppm}$ and added more nutrients than might occur even in temperate polluted sites. Thus, new experiments are required to investigate the effects of more realistic increases in litterfall using litter with low nutrient concentrations.

\section{Data availability}

The data used in this paper can be found in the tables in the Supplement.

\section{The Supplement related to this article is available online at doi:10.5194/bg-13-6183-2016-supplement.}

Acknowledgements. We thank J. Bee, L. Hayes, S. Queenborough, R. Upson and M. Vorontsova for surveying the plots, J. Bee for setting up the experiment in 2000 and 2001; E. Sayer for running the experiment from 2001-2009; A. Vincent for helping to maintain the experiment from 2003-2005. T. Jucker did the statistics to compare the effect of treatment on soil $\mathrm{C}$ relative to mineral matter. Funding for the project was originally from the Mellon Foundation (1999-2002); ongoing costs were paid for by the Gates Cambridge Trust (E. Sayer); The University of Cambridge Domestic Research Studentship Scheme and the Wolfson College Alice Evans Fund (A. Vincent); and The Drummond Fund of Gonville and Caius College and Cambridge University (E. Tanner). The whole of the experiment depended on the continuous raking of litter, which was done by Jesus Valdez and Francisco Valdez. We thank D. Agudo and T. Romero for doing the laboratory work and J. Rodriguez for collecting the samples in the forest. S. J. Wright has been a frequent source of help for many aspects of the experiment.

Edited by: S. Zaehle

Reviewed by: W. Wieder and one anonymous referee

\section{References}

Bowden, R. D., Deem, L., Plante, A. F., Peltre, C., Nadelhoffer, K., and Lajtha, K.: Litter input controls soil carbon in temperate deciduous forest, Soil Sci. Soc. Am. J., 78, s66-s75, 2014.

Burnham, K. P. and Anderson, D. R.: Information and likelihood theory: a basis for model selection and inference, in: Model Selection and Multimodel Inference, edited by: Burnham, K. P. and Anderson, D. R., Springer New York, 49-97, 2002.

Clemmensen, K. E., Bahr, A., Ovaskainen, O., Dahlberg, A., Ekblad, A., Wallander, H., Stenlid, J. Finlay, R. D., Wardle, D. A., and Lindahl, B. D.: Roots and associated fungi drive long-term carbon sequestration in boreal forest, Science, 339, 1615-1618, 2013.

Cleveland, C. C., Townsend, A. R., Taylor, P., Alvrez-Clare, S., Bustamente, M. M. C., Chuyong, G., Dobrowski, S. Z., Grierson, P., Harms, K. E., Houlton, B. Z., Marklein, A., Parton, W., Porder, S., Reed, S. C., Sierre, C. A., Silver, W. L., Tanner, E. V. J., and Wieder, W. R.: Relationships among net primary productivity, nutrients and climate in tropical rain forest: a pan-tropical analysis, Ecol. Lett., 14, 939-947, 2011.

Jobbagy, E. G. and Jackson, R. B.: The vertical distribution of soil organic carbon and its relation to climate and vegetation, Ecol. Appl., 10, 423-436, 2000.

Koehler, B., Corre, M. D., Steger, K., Well, R., Zehe, E., Sueta, J. P., and Veldkamp, E.: An in-depth look into a tropical lowland forest soil: nitrogen-addition effects on the contents of $\mathrm{N}_{2} \mathrm{O}, \mathrm{CO}_{2}$ and $\mathrm{CH}_{4}$ and $\mathrm{N}_{2} \mathrm{O}$ isotopic signatures down to 2-m depth, Biogeochemistry, 111, 695-713, 2012.

Körner, C.: Plant $\mathrm{CO}_{2}$ responses: an issue of definition, time and resource supply, New Phytol., 172, 393-411, 2006.

Lajtha, K., Townsend, K. L., Kramer, M. G., Swanston, C., Bowden, R. B., and Nadelhoffer, K.: Changes to particulate versus mineral-associated soil carbon after 50 years of litter manipulation in forest and prairie experimental ecosystems, Biogeochemistry, 119, 341-360, 2014a.

Lajtha, K., Bowden, R. D., and Nadelhoffer, K.: Litter and root manipulations provide insights into soil organic matter dynamics and stability, Soil Sci. Soc. Am. J., 78, s261-s269, 2014b.

Leff, J. W., Wieder, W. R., Taylor, P. G., Townsend, A. R., Nemergut, D. R., Grandy, A. S., and Cleveland, C. C.: Experimental litterfall manipulation drives large and rapid changes in soil carbon cycling in a wet tropical forest, Glob. Change Biol., 18, 2969-2979, 2012.

Lichter, J., Barron, S. H., Bevacqua, C. E., Finzi, A. E., Irving, K. F., Stemmler E. A., and Schlesinger, W. H.: Soil carbon sequestration and turnover in a pine forest after six years of atmospheric $\mathrm{CO}_{2}$ enrichment, Ecology, 86, 1835-1847, 2005.

Lichter, J., Billings, S. A., Ziegler, S. E., Gaindh, D., Ryals, R., Finzi, A. C., Jackson, R. B., Stemmler, E. A., and Schlesinger, W. H.: Soil carbon sequestration in a pine forest after 9 years of atmospheric $\mathrm{CO}_{2}$ enrichment, Glob. Change Biol., 14, 2910 2922, 2008.

Nemani, R. R., Keeling, C. D., Hashimoto, H., Jolly, W. M., Piper, S. C., Tucker, C. J., Myneni, R. B., and Running, S. W.: Climatedriven increases in global terrestrial net primary production from 1982 to 1999, Science, 300, 1560-1563, 2003.

Nottingham, A. T., Turner, B. L., Stott, A. W., and Tanner, E. V. J.: Nitrogen and phosphorus constrain labile and stable carbon 
turnover in lowland tropical forest soils, Soil Biol. Biochem., 80, 26-33, 2015.

Pinheiro, J. and Bates, D.: Mixed-effects Models in S and S-PLUS, Springer, New York, 548 pp., 2000.

Porder, S. and Chadwick, O. A.: Climate and soil-age constraints on nutrient uplift and retention by plants, Ecology, 90, 623-636, 2009.

Powlson, D. S., Whitmore, A. P., and Goulding, K. W. T.: Soil carbon sequestration to mitigate climate change: a critical reexamination to identify the true and the false, Eur. J. Soil Sci., 62, 42-55, 2011.

Quesada, C. A., Lloyd, J., Anderson, L. O., Fyllas, N. M., Schwarz, M., and Czimczik, C. I.: Soils of Amazonia with particular reference to the RAINFOR sites, Biogeosciences, 8, 1415-1440, doi:10.5194/bg-8-1415-2011, 2011.

Rasse, D. P., Rumpel, C., and Dignac, M.-F.: Is soil carbon mostly root carbon? Mechanisms for a specific stabilisation, Plant Soil, 269, 341-356, 2005.

Sayer, E. J. and Tanner, E. V. J.: Experimental investigation of the importance of litterfall in lowland semi-evergreen tropical forest nutrient cycling, J. Ecol., 98, 1052-1062, 2010.

Sayer, E. J., Tanner, E. V. J., and Cheesman, A. W.: Increased litterfall changes fine root distribution in a moist tropical forest, Plant Soil, 281, 5-13, 2006.

Sayer, E. J., Powers, J. S., and Tanner, E. V. J.: Increased litterfall in tropical forests boosts the transfer of soil $\mathrm{CO}_{2}$ to the Atmosphere, PLoS ONE, 2, e1299, doi:10.1371/journal.pone.0001299, 2007.

Sayer, E. J., Heard, M. S., Grant, H. K., Marthews, T. R., and Tanner, E. V. J.: Soil carbon release enhanced by increased tropical forest litterfall, Nature Clim. Change, 1, 304-307, 2010.

Sayer, E. J., Wright, S. J., Tanner, E. V. J., Yavitt, J. B., Harms, K. E., Powers, J. S., Kaspari, M., Garcia, M. N., and Turner, B. L.: Variable responses of lowland tropical forest nutrient status to fertilization and litter manipulation, Ecosystems, 15, 387-400, 2012.

Schmidt, M. W. I., Torn, M. S., Abiven, S., Dittmar, T., Guggenberger, G., Janssens, I. A., Kleber, M., Kogel-Knabner, I., Lehmann, J., Manning, D. A. C., Nannipieri, P., Rasse, D. P., Weiner, S., and Trumbore, S. E.: Persistence of soil organic matter as an ecosystem property, Nature, 478, 49-56, 2011.
Schreeg, L. A., Mack, M. C., and Turner, B. L.: Leaf litter inputs decrease phosphate sorption in a strongly weathered tropical soil over two time scales, Biogeochemistry, 113, 507-524, 2013.

Schwendenmann, L. and Pendall, E.: Response of soil organic matter dynamics to conversion from tropical forest to grassland as determined by long-term incubation, Biol. Fert. Soils, 44, 10531062, 2008.

Tanner, E. V. J., Vitousek, P. M., and Cuevas, E.: Experimental investigation of nutrient limitation of forest growth on wet tropical mountains, Ecology, 79, 10-22, 1998.

Trumbore, S. E.: Age of soil organic matter and soil respiration: radiocarbon constraints on belowground $\mathrm{C}$ dynamics, Ecol. Appl., 10, 399-411, 2000.

Turner, B. L. and Romero, T. E.: Short-term changes in extractable inorganic nutrients during storage of tropical rain forest soils, Soil Sci. Soc. Am. J., 73, 1972-1979, 2009.

Turner, B. L., Yavitt, J. B., Harms, K. E., Garcia, M., and Wright, S. J.: Seasonal changes in soil organic matter after a decade of nutrient addition in a lowland tropical forest, Biogeochemistry, 123, 221-235, 2015.

Vincent, A. G., Turner, B. L., and Tanner, E. V. J.: Soil organic phosphorus dynamics following perturbation of litter cycling in a tropical moist forest, Eur. J. Soil Sci., 61, 48-57, 2010.

Wieder, W. R., Cleveland, C. C., Taylor, P. G., Nemergut, D. R., Hinkley, E.-L., Philippot, L., Bru, D., Weintraub, S. R., Martin, M., and Townsend, A. R.: Experimental removal and addition of leaf litter inputs reduces nitrate production and loss in a lowland tropical forest, Biogeochemistry, 113, 629-642, 2013.

Wright, S. J., Yavitt, J. B., Wurzburger, N., Turner, B. L., Tanner, E. V. J., Sayer, E. J. Santiago, L. S., Kaspari, M., Hedin, L. O., Harms, K. E., Garcia, M. N., and Corre, M. D.: Potassium, phosphorus, or nitrogen limit root allocation, tree growth, or litter production in a lowland tropical forest, Ecology, 98, 1616-1625, 2011.

Zuur, A. F., Leno, E. N., Walker, N., Saveliev, A. A., and Smith, G. M.: Mixed Effects Models and Extensions in Ecology with R, Springer, New York, 574 pp., 2009. 